\title{
200-HUNDRED YEAR CLIMATE RECORD FROM ANTARCTIC PENINSULA
}

(Abstract)

\author{
by
}

D.A. Peel and R. Mulvaney

(British Antarctic Survey, Natural Environment Research Council, High Cross, Madingley Road, Cambridge CB3 0ET, U.K.)

\begin{abstract}
A stable isotope record extending back to 1795 is now available from Dolleman Island $\left(70^{\circ} 35.2^{\prime} \mathrm{S}, 60^{\circ} 55.5^{\prime} \mathrm{W}\right)$, a small ice rise on the Weddell Sea coast of Antarctic Peninsula. An accurate chronology has been achieved by combined stratigraphic analysis of clear seasonal cycles in $\delta^{18} \mathrm{O}$ and excess $\mathrm{SO}_{4}$. Previous work (Peel and others, 1988) has shown that, since 1947, there is generally a satisfactory correlation between interannual variations in $\delta^{18} \mathrm{O}$ and air temperature $(\mathrm{T})$ as recorded at weather stations in various parts of the region, suggesting that the derived $\delta^{18} \mathrm{O} / \mathrm{T}$ ratio may be used to reconstruct air temperatures for the earlier period.

Taken together with previously-reported data (Aristarain and others, 1986) for an ice core from James Ross Island it is now possible to propose a regional climatic signal for the Weddell Sea coastal sector of the region. The most striking feature is a broad maximum in $\delta^{18} \mathrm{O}$ for the mid-19th
\end{abstract}

\begin{abstract}
century, implying decadal average temperature at least as high as the present. This contrasts with available evidence from elsewhere in the southern hemisphere which suggest that this period was cooler than today. Tentative explanations for the anomaly are proposed based on evidence for a period (1974-80), where climatic shifts are clearly amplified in the isotopic records.
\end{abstract}

\section{REFERENCES}

Aristarain, A.J., J. Jouzel and M. Pourchet. 1986. Past Antarctic Peninsula climate $(1850-1980)$ deduced from an ice core isotope record. Climatic Change, 8, 69-89.

Peel, D.A., R. Mulvaney and B.M. Davison. 1988. Stable isotope/air-temperature relationships in ice cores from Dolleman Island and the Palmer Land Plateau, Antarctic peninsula. Ann. Glaciol., 10, 130-136.

\section{RECENT TERMINUS BEHAVIOR OF NORTH CASCADE GLACIERS, WASHINGTON, RELATED TO CLIMATIC SENSITIVITY}

\author{
(Abstract) \\ by \\ Mauri S. Pelto \\ (Department of Geological Sciences and Institute for Quaternary Studies, \\ University of Maine, Orono, ME 04469, U.S.A.)
}

Since 1977 ablation-season temperature has been $1.1^{\circ} \mathrm{C}$ above the 1930-80 mean and winter precipitation has been $14 \%$ below the 1930-80 mean. In order to identify the effect of this climatic fluctuation on North Cascade glaciers, the North Cascade Glacier-Climate Project has monitored the terminus behavior of 107 glaciers between 1983 and 1988.

The 107 glaciers examined represent six climate sensitivity groups. Each group has a different sensitivity to the four primary climatic parameters: (1) ablation-season temperature, (2) accumulation-season precipitation, (3) summer cloud cover and (4) freezing levels during May and October precipitation events. A glacier's sensitivity to each climatic parameter is determined by its geographic location and topographic position. Each sensitivity type has specific geographic and topographic characteristics, such as degree of radiational shading, orientation, altitude with respect to the local glaciation threshold, accumulation sources, and distance from the Cascade Crest. Accumulation sources are direct snowfall, wind drifting and avalanching.

Of the 107 glaciers examined, 91 had retreated significantly between 1983 and 1988 and three had advanced. Correlation of retreat rate and climatic sensitivity type indicates that the higher a glacier's winter balance, the smaller the retreat rate. High-altitude accumulation zones, multiple accumulation sources and a northward orientation are all associated with higher winter balances. Retreat was greatest for glaciers with poor radiational shading, and only direct snowfall accumulation. Retreat rate was slowest for glaciers with multiple accumulation sources and a northward orientation, though not necessarily good radiational shading. Retreat rate increased with distance east of the Cascade Crest and retreat rate was high for low-altitude glaciers. 